\title{
INTER-RELIGIOUS HARMONY BETWEEN HINDU MUSLIM GROUPS IN NEPAL.
}

\author{
Niranjan Ojha, PhD*
}

\begin{abstract}
:
Religious harmony is very important to maintain peace and stability in a country like Nepal where people are multi-religious. Failure to address religious harmony it could take the society into conflict. Though Nepal is a Hindu dominant secular country the Muslims are an important and inseparable part of Nepalese community. They have been living in Nepal since last 500 years with religious harmony. During this period there were negligible religious riots between Hindu and Muslims. Social acceptance and recognition given to the Nepali Muslims, they were integrated in such a way, became inseparable part of the society. But in recent years they have tried to differentiate themselves religiously challenging centuries old harmony and peace. In the process they have undergone a process of political Islamization and have emerged as a distinctive ethnic community. It has shown a danger of deadly encounter between Hindu-Muslim religion groups. This paper tries to discuss the fundamental factors contributing to religious in a multireligious society. FGD and library research method is used in addressing the situation of religious harmony. This paper also emphasizes that elements such as acceptance, understanding, co-operation as well as right and justice are significant elements in sustaining religious harmony. Hence, the discussion is aimed to build a sustainable concept of multi-religious harmony in Nepal. The findings could encourage maintaining strong relationship among them.
\end{abstract}

Keywords: Nepali Muslims, Religious Harmony, Hindu- Muslim relations, Religious riots, Conflict, Acceptance.

\section{Background}

Nepal is inhabited by heterogeneous religious groups. The composition of Nepali society according to religion is as follows -

Hindus $-81.34 \%$, Buddhists - $9.04 \%$, Islam $\quad-4.38 \%$, Kirat-3.04 \%, Christianity $-1.41 \%$ and others (Census 2011)

The total number of Muslim population according to census 2011 is 1162370. As per 2011 census report, Muslims constitutes $4.38 \%$ of the total population, the third largest religious group. Four districts of the Terai namely Banke, Kapilbastu, Parsa and Rautahat with over $50 \%$ of the Muslim population are the Muslim - majority districts. The five districts namely Bara, Mahottarai, Dhanusa, Siraha and Sunsari are the second Muslim majority districts and the two districts Rupendehi and Sarlahi constitutes as a significantly third religious group (Census 2011). Kathmandu Valley and Hilly area also have small Muslim population.

* Associate Professor of Saraswati Multiple Campus (Humanities Faculty, History Department), Tribhuvan University, Nepal 


\section{Statement of the Problem}

The Muslims came to Nepal in different times for different purposes and settled in different geographical regions. The Muslims, in Nepal, everywhere, they are living in the places surrounded by the Hindus. It has a greater impact in their culture, social behavior, attitude, understanding and co-operation to promote religious harmony. The Muslims of Nepal living in different places held both liberal and orthodox attitude in socio-religious activities. The hill Muslims, Tibetan and Kashmiree Muslims of Kathmandu Valley are very liberal in socioreligious matter whereas Terai Muslims and Indian immigrants are orthodox and rigid with their Hindu and other religious neighbours. Beauty of Nepali society is- in 500 years history, Muslims could not penetrate the Hindu culture and religion and the Hindus never tried to penetrate Muslim culture and religion. This overall situation is important on the study of religious harmony.

The Nepali Muslims are not given proper attention by the researchers to go through the study and has not been studied yet academically. Some national and international articles tried to address the religious harmony between the religious groups of Nepal but they don't cover the overall aspects. This article intends to identify some unidentified problems of religious tolerance between Hindu and Muslims.

\section{Research Question}

So many such problems have been raised by so many researchers listed in review of literature. There are some areas which are not addressed that are being focused by this research.

The research tries to answer following question,

1. What is the social status of Muslims of Nepal?

2. How is the interreligious relation between Hindu and Muslims in Nepal?

\section{Objective of the study}

In order to present the study two main objectives were selected:

1. To identify the social status of Nepali Muslims.

2. To analyze the interreligious relation of Nepali Muslims.

\section{Review of the Literature}

Before proceeding to the topic under investigation, it is rather very much rational to review already published literature dealing with different aspects of Nepali Muslims. A thorough review of literature certainly helps to identify research problems, present situation and research gap on the area of research.

No significant work has been published on Muslims of Nepal with an exception of Gaborieau, Quresa Banu, Shanker Thapa, Abdul Salam khan, Niranjan Ojha and David Seddon on such a vague topic. All other works available so far, are in the forms of mini research projects sponsored 
by TU., published research articles in leading journals both in home and abroad. All these published and unpublished references are reviewed before proceeding to the research. The first and foremost place in the study and survey of Nepali Muslims is recurred by Frenchman Marc Gaborieau; he has extensively visited and surveyed Muslim settlements in the western hills. Gaborieau's works inaugurated Muslims studies in the Hindu state of Nepal ever since early sixties of the $20^{\text {th }}$ century. The academicians and other researchers in Nepal are found to be bias towards Nepali Muslims while identifying research problems. The native scholars are usually reluctant to deal with them without any specific reasons.

Gaborieau (1977) "Minorities Musalmanes dans le royaume hindou du Nepal” primarily deals with the history and ethnography of Muslims minority in Nepal. Likewise, Gaborieau has published many research articles on Muslims covering wide variety of themes from hills to Tarai. Those articles are -

Les Musalman du Nepal, object et mondes (1966), Les curute du moyen Nepal place d'un groupe du musalmans dans the society des castes (1966), Muslims in Hindu kingdom of Nepal (1977), Aspects of lineage among the Muslim Bangle makers of Nepal (1978), Life cycle ceremonies of converted Muslims in Nepal and northern India (1984).

Abdul Salam Khan (2071 B.S.) provides general information of the Nepali Muslims in his book "Nepal Ra Nepali Musalman". His book is basically focused on socio-economic status of Nepali Muslims of Kapilbastu.

David Seddon (2018) "The Muslim Communities of Nepal” is based on a field study report. It is focused on socio- cultural as well as political conditions of Nepali Muslims of Terai.

Niranjan Ojha and D.S. Kunwar (2018) critically analyze the history, social status and economic life of Muslim community in their book "Muslims of Nepal: Social, Historical and Economic perspectives".

Shanker Thapa (1986) has done very meaningful works on Nepali Muslims. His contributions entitled "A study of population and family planning among the Muslims in a Nepalese Town" and "Caste Hierarchy among Muslims" (1995) are the incredible research in the field of Nepali Muslims. He has covered almost all the area on the Terai Muslims.

Quraisha Banu (1980) provides informative and general glimpse of Nepali Muslims in her Master's thesis “Introduction to Muslims in Nepal". This research deals with the historical aspects of Muslim social system, religion, festivals and rituals, status of women and family life of Muslims of Kathmandu.

\section{Research Gap}

The literature review is a major component to formulate conceptual frame. The purpose is to situate the proposed research in the context of what has already been done in the field. It helps to narrow down the proposed topic.

So far as these publications are concerned, these varied topics provide invaluable information on different aspects of Nepali Muslims. These literatures are helpful to identify research problems and to generate the ideas. It gives an idea on research and support to analyze the present situation of 
research. It is also helpful to generate research tools for further study. But it doesn't cover the present situation of harmony between Hindu-Muslim relations of Nepal.

Some national and international articles, books and reports tried to address the different aspects of Nepali Muslims but they don't cover the actual status of Nepali Muslims. These literatures don't support the raised research questions but it is partially helpful to fulfill theoretical aspects. This article intends to identify some unidentified problems of Hindu-Muslim social harmony in Nepal in general. Hence, I have reviewed the available literature to explore the research gap.

\section{Methodology}

This article is based upon a qualitative analysis. Explanatory, descriptive, analytical as well as informative method has been used in this research. Focus group discussion (FGD) was done to collect the first hand information on the topic. For more general discussions, focused group discussion (FGD) has been organized in the entire above mentioned topic. Three separate focused group discussions have been organized with Muslims Scholars, University Professors and ordinary Muslims people. For FGD mainly discussion method was used. Both formal and informal discussion was held with the concern stake holders. For FGD, resource persons were selected as respondent from Jame Masjid (Moulana Mohasin), Kashimree Taqia (Fazir Miya), Saukat Ali (Univeristy Profesor), Akbar Khan (Businessman), Tara Devi (Converted Muslim lady), Tavil Ansari (Journalist), Atala Bhai (Royal Cook) and Abdul Majid (Civil Servant).

This research consists of present context data but some historical references are cited in the appropriate places. Basic source of information for this research is primary as well as secondary information. For secondary information basically library research method is used. Relevant books, journal articles, online websites and related publications have been used properly. All the information collected has been classified, summarized, analyzed and some reflection will be made for this research.

This study is limited to historical study of Hindu-Muslim relations. This study doesn't cover the social, political, legal, economic and other aspects of Hindu-Muslim relationship.

\section{Discussion}

Nepal, a small Himalayan country is the home land for several castes, ethnic, linguistic and religious groups. Majority population of Nepal is Hindu. Besides, there are other religious people residing in Nepal as minorities.

If we look at the Nepali national population, different geographical region has specific ethnic groups. The Himalayan region is occupied by the mongoloid race whereas Terai is occupied by the people of Indian origin including - plane caste and tribes. Kathmandu valley is the composition of all tribes, ethnic and religious groups. Majority of Muslim population live in the southern plane of the country. They live both in rural and urban area from east to west. They have a good number in this region. Considering Muslims, a small number of Muslims live in the Hilly areas and in Kathmandu as a distinctive religious group (CBS 2011). 
The total number of Muslim population according to census 2011 is 1162370. Muslims constitutes $4.38 \%$ of the total population (Census 2011), the figure claimed by the Muslim organizations is much more than the census data. Speedy migration from the Indian plane to the Terai considerably contributed to this increase. Migration from Indian plane to Terai is steady and consistent. Four districts of the Terai namely Banke, Kapilbastu, Parsa and Rautahat with over 50 $\%$ of the Muslim population are now Muslim - majority districts. The five districts namely Bara, Mahottarai, Dhanusa, Siraha and Sunsari are the second muslim majority districts and the two districts Rupendehi and Sarlahi constitutes as a significantly third religious group(CBS: 2011:34). Kathmandu Capital of Nepal contributes 21866 Muslim populations which is $1.25 \%$ of Kathmandu population (www.nmc.gov.np).

\section{Historical Situation}

Historically, it is difficult to come to any conclusion of Muslim settlement in Nepal. Historical evidences supports that there was certain kind of commercial relation between Nepal and Arabia (Regmi: 2026:150). In the year 1324 A.D., Muslims entered Nepal for the first time in the history, it was not the migration. Gayasuddhin Tuglak entered Simraungarh when he was returning to Delhi from Calcutta. In the year 1349 A.D., another Muslim ruler, Sultan of Bengal, Samasuddhin Ilyas invaded Kathmandu Valley (Banu: 1980:23). This was neither the migration nor the immigration just invasion. Later they returned back.

The first arriving Muslims in Nepal were the Kashmiree merchants. They came to Nepal via Laddhak and Tibet during the reign of King Ratna Malla, the ruler of Kathmandu. This marked the beginning of the history of Muslim population in Kathmandu. The main purpose of their arrival was to trade in Nepal (Subedi: 2040:11). The second batch of Muslims came to Nepal, particularly Kathmandu during the reign of King Pratap Malla of Kathmandu in $17^{\text {th }}$ century; they are the Hindusthani Muslims (Gaborieau: 1981:199-200). The third batch came to Nepal during the reign of Bhaskar Malla(1700-1722 A.D.) . The fourth batch entered at the time of Jaya Praksh Malla, the last Malla King. King Prithivi Narayan Shah, the ruler of Gorkha, had also invited Muslim arm experts from India. Likewise, King Ram Shah of Gorkha invited Muslims people to settle in Gorkha. All those Muslims, settled in remote hill village, began to engage in bangle selling, are now called the Churauteys. Similarly, King Mahodatta Sen of Palpa invited Muslim arm experts from India. Likely, King Damodar Sen of Tanahun also had invited Muslims from Oudh. This immigration was before the unification campaign (Ojha: 2018:4).

Later, they were settled in different parts of Nepal including Kathmandu valley. Major arrival of Muslims in Nepal was in its Terai region during and after Sepoy Mutiny of 1857 A.D. (Indian Historian said it as first independent movement). Jung Bahadur Rana gave protection and shelter to the Begum Hazrat Mahal, Begum of Oudh. Knowing about the migration of Begum, the Muslims from Indian border area started migration to the Terai region of Nepal. Because of geographical reason and malaria hill people were not very much interested to migrate to the Terai that's why Indians were encouraged to immigrate. So, a considerable number of Muslim farmers came to this region. In this way Muslims came to Nepal and permanently settled here (Ojha: 2016:103). Until the reign of Ratna Malla, Muslims were not permanently settled in Nepal. Now it should be clear that Muslims were invited to Nepal to settle here they didn't came here as invaders. In other Asian countries especially in the then India (India, Pakistan and Bangladesh) 
they came as invaders. They ruled India for centuries. They settled there as winners and other religious people who were defeated (the losers) they were ruled by the Muslims in their country. This is the basic difference between Nepali Muslim settlement and other countries Muslim settlement. This is the major cause for peace and harmony between Hindu- Muslim religious groups.

\section{Classification of Nepali Muslims}

Because of the differences in belief, Nepali Muslims are also divided into the Sunni and the Shias. In Nepal an overwhelming majority of the Muslims belong to the Sunni sect. Shias are insignificant in population. The Sunni's they themselves splited into different sub-sects because of the variations in belief on aspects of religion as other countries. Some refer to Muslim mystics, the Sufis, as a sect of Islam. They are however, considered as Sunni (Thapa: 1995:55). So, as far as the Muslim society of Nepal is concerned, the entire belief system is borrowed from their counterparts in India. A large number of Nepali Muslims are either trained or influenced by the orthodox Deoband School but some Muslims have an influence of Barelvi School though they are very few in number these days. Fajir Miya, Chief of Kashmiree Taquia said that before few decades Barelvi School used to be a major school and their followers were in majority in Nepal. When speedy migration took place from Indian plane most of the Barelvees were either converted into Deobandi or Deobandi dominated Barelvi in religious matter because Barelvi they don't have easy access to religious school and scholars in India comparing Deobandi.

Many native and foreign scholars had classified Nepali Muslims into different groups according to their residential status. Abdul Salam Khan (2071B.S.) in his book "Nepal ra Nepali Musalman" has classified Nepali Muslims into five categories (Khan: 2071:30), David Seddon( 2018) in his book "The Muslim Communities of Nepal" has classified them into Six categories( Seddon:2018:V). They have classified Nepali Muslims according to their residential status not their indigenous features. According to their indigenous features they can be classified only into three categories (Ojha: 2018:13). Thus, the Muslims of Nepal are mainly divided into three major groups according to their indigenous features. They are- The Kashmiree, Tibetan Muslims and Indian Muslims.

\section{Social Harmony between Hindu- Muslim in Nepal}

Though Nepal is a Hindu dominant secular state (declared by the constitution of Nepal 2015 ), Nepali legal system has been borrowed from various sacred Hindu Smritis, Vedas and other texts. Therefore, Nepali law is originated from the Hindu religion. So, the legal system is uniform. There is no separate law for religious or ethnic groups as in India. Religious freedom is granted to people (Siwakoti: 2072:95). There are various such laws and regulations which are not compatible with the Islamic culture. Laws extracted from the Hindu jurisprudence are neither friendly nor hostile to the Islamic culture but the state never discriminated them. They have opportunities to hold government positions, participate in political activities, practice religion and so forth.

Therefore, along with other minor religion, Islam existed since its first arrival in the 15th century strictly in the Nepali form. They are scattered everywhere. Almost every place, they live, is 
surrounded by the Hindus. It obviously has greater impact in the culture and belief system. The Muslims in Western hills and in Kathmandu, Bhaktapur and Patan, since their first arrival, they are living in Hindu environment. During the 500 years history of Muslims minority in Nepal, the Hindu religious tenets and cultural components of cultural change are always active to create dynamism in cultural pattern( Ojha:2011:95-99).

The Muslims of Nepal living in different places held both liberal and orthodox attitude in religion and culture. Usually, the hill Muslims, the Kashmirees and Tibetan Muslims in Kathmandu and hill settlement are very liberal in religious matters whereas other Muslim communities in Kathmandu and Terai plane, such as the Terai Muslims or Indian immigrants are found to be very much orthodox in religious matters. Even in that situation, the process of religious modernization has brought about perceptible change in such attitudes. The Nepali Muslims are almost 500 years old religious community, during this time, they tended to change themselves to the extent they were able to adopt various indigenous features blended in their religion and culture and marked their presence in the mainstream of national culture. (Ojha:2011:95-99)

Religious syncretism between Hindu and Islam is clearly visible in Nepal. Prithivi Narayan Shah during his regime (1743-1775 A.D.) unified various independent hill kingdoms into modern Nepal. Before his death in 1775 A.D. he recorded the "Divya Upadesh" (divine message), which was a part of the guiding principles for the state administration. In his "Divya Upadesh" he had endorsed his kingdom as a land of Hindus, contrasting with Mughlan, the land polluted by the rule of the Mughals and their successors (Whelpton: 2005 :56). India was known as Mughalan as a common Nepali language. It is said that the people of Nepal made it a custom not to drive out the cow, the national animal from their field in south direction to stop its entry in Mughlan, where there was no state restriction on cow-slaughter. Jang Bahadur, the first Rana Prime minister in the kingdom of Nepal expanded the "Divya Upadesh" and framed "Muluki Ain"(law of land)1854 A.D. for strict implementation of the caste order base Hindu Social code, which listed the Muslims in the category of impure and untouchables. In fact the people of Nepal (the Hindus) tolerated Muslims with restrictions to the extent that only "raw and dry" eatables were acceptable from their hands ( Gaborieau : 1981: 209).

The Muslims of Nepal strictly followed the Nepal code of 1854 A.D. and accepted lower social status as loyal citizens and accordingly maintained a very low profile under the Hindu Monarchy system of governance. It may be interesting to note that even after their long presence in Nepal during the Monarchy there was hardly any significance of communal problem in Nepal. The end of Rana regime in 1951A.D. and establishment of Multi-party democracy hardly made any change in the social status of Muslims. The situation remained same even up to 1959 A.D. King Mahendra dismissed B.P.Koirala's government in 1960 A.D. and introduced party less Panchayat system (Mananddhar and Sharma : 2053: 112). He replaced the 1854 A.D. code in 1963A.D. which provided equal citizen status to the Muslims. Although, the new code allowed the Muslims to practice their religion freely, the ban on conversion or dissolution of marriage etc. remained as it was in 1854 A.D. Any attempt to convert people remained a punishable offence. The King however, nominated one Muslim in his National Panchayat and there was no restriction on opening of madrassas. Even though 1963 A.D. code did not alter the social status of the Muslims, it opened a floodgate for the various Islamic groups from across the border to expand their activities in Nepal. 
Muslims, the third religious groups in Nepal were allowed to practice their faith under certain restrictions. They were debarred from propagation of Islam or to follow Islamic code Shariat. It is something amazing to see how this significant number of followers of Islam compromised with anti-Shariat (Islamic laws) un-Islamic Hindu environment and lived here peacefully for centuries.

\section{Causes behind religious Harmony}

Root cause of Hindu- Muslim religious harmony in Nepal, as I believe, firstly is the continuity of Divya Upadesh introduced by King Prithivi Naraysn Shah and the implementation of Hindu civil code of 1854 A.D. inspired by Manusmriti. The rulers after then, the Monarchy, the active Monarchy, the Constitutional Monarchy and even in the first phase of republican, whatever they were, they followed Prithivi Narayan Shah and Jung Bahadur Rana. Continuation of Hindu civil code was strict and never accepted Muslim law -Sariyat which contributed religious harmony. Besides there are other causes which are responsible for religious harmony. They are -

\section{Arrival}

The first and foremost cause of religious harmony in Nepal is their arrival. It should be noted that Muslims came to Nepal as invitees not the invaders. Nepali rulers had invited them to settle here. In Nepal, we have a culture to respect guest- Atithi Devo Bhawa meanings guests are the Gods. Muslims were treated in the Nepali society as guests. That's why society gave them respect and never tried to discriminate them on the basis of their belief system thus they blended in the society.

\section{Social Acceptance}

According to Hindu civil code of 1854 Muslims were in the category of untouchable and impure caste, only "raw and dry" eatables were acceptable from their hands but during Monarchial system, King used to call Muslim Cook in his Friday family party in the palace. Nepali King was represented as an incarnation of Hindu God Vishnu in the society. A Hindu King gave such respect to the Muslim community avoiding the civil code which was an ice-break in the orthodox Hindu society. It has done just for religious harmony (discussion with Atala Bhai- Muslim Cook). These days, Hindus rush to Muslims restaurants for delicious food. Muslim food (Halal food), now a days is much more popular than the traditional food.

\section{Social Respect}

During $18^{\text {th }}$ century Mahindra Singh Malla had invited Muslim Ustad (singer) to his palace (Subedi: 2074 : Ca) and he was granted a high level post in his palace. King Rana Bahdur Shah had appointed Kaiyum Kha Kalwar as Royal vocalist. He had appointed Jivan Shah Kalwar and Bhawani Shah Kalwar as an incharge of music-dance department (Subedi: 2074 : Ca). High rank position granted to Muslims is the sign of social respect.

\section{Social Recognition}

Narayanapur, in Banke district is the place where Hindu- Muslim coincides together. Majar of Khalipha Nur Ahmad Shah and Majar of Hajrat Baba Kammar Shah, Muslim majar, are the sacred place for Hindus where Hindu offered blanket (Chadar) and Muslims pray in Musbetwa 
Baba temple, a Hindu temple. Religiously, Hindu and Muslims both gave equally recognition to their religion and accepted each other as inseparable part of the society (BBC,Feb 2021).

\section{Co-operation}

The element of co-operation is very important to build good relation between the religious groups. With the existence of this element in their life, they will respect and tolerate other religion. Cooperation can be seen through their action by respecting the celebrations, rituals as well as beliefs of other religious matter in their community. Hindu and Muslims of Terai, both they celebrate Chhat festival as their own festival.

\section{Constitutional Right}

Constitution of Nepal has granted equal right to the Muslims without discriminating them as minority. Muslims are enjoying equal right such as Civil right, Political right, Right to freedom, Property right like their Hindu counterpart from the very beginning. The Muslims have even held high offices. The percentage of such is not discouraging. Many of the prominent Muslims are member of parliaments, minister's, civil servant of higher status, professors, lawyers, scientists, medical practitioners, engineer and so on. They have equally contributed to nation building.

\section{Government Policy}

The government took account of welfare of Muslims and protection of their religious rights. The Home Ministry always manages Haj pilgrimage safely and easily with financial support. Muslims Commission, constitutional body, has been formed for the welfare of the Muslims. Muslims are getting reservation in official appointment, education and so on. Though Nepal is a declared secular state but there is no separate law (Seriate) and Muslim Personal Law board for Muslims considering them equal.

\section{Religious Protection}

Kashmiree Taquia and Nepali Musk (Jame Masjid) is very closer to the King's Palace (about 300 meters) in the core city surrounded by the Hindu temples which is the example of state policy for religious protection.

These are few examples of the Nepali Hindu rulers that they have accepted Muslims as their own citizen and granted high official value. They never tried to discriminate Muslim because of their religious belief. Though culturally Muslims are very different to Hindus in religious matters but the Nepali Muslims they participate in Hindu festivals and rituals and the Hindus they do the same. Some Muslims, after the promulgation of secular constitution, they are demanding Hindu state as before. There are other significant causes responsible to religious syncretism.

This kind of existing situation has contributed the Muslims to strengthen their root in the Nepalese society. They feel Nepal at first then religious groups. Muslims has a great contribution during unification campaign. Thus, Nepali national feeling is in the heart of every Nepali Muslims. 


\section{Conclusion}

It is important to note that living in a harmonious society without conflict and tension is very important for national development. No single person in this world would like to live in tension, conflict, and war. Thus, strengthening unity and solidarity among religious groups is essential to create a harmonious society. Inter-religious harmony should be built based on trust and mutual respect among multi-religious groups.

Nepali rulers of Medieval and modern period, they never adopted policies that was against the welfare of the Muslims and their existence. The Muslims of Nepal have lived in harmonious syncretism with their Hindu and other religious neighbors for centuries. Nepali Muslims they never tried to differentiate them as separate religious group even after the declaration of secular constitution. Still they are demanding Hindu State instead of secularism. They said they were safe in Hindu Nepal and their life was much better then present day.

The political movement of 2062/063 B.S., has a great importance in the history of Nepal. It has created a new political scenario in Nepal. Declared Hindu State has been changed into secular Nepal. Feudal democratic system as well as constitutional monarchial system has been transformed into federal democratic republican system. Hindu character of the constitution, which was the back bone of cultural assimilation and religious syncretism, which has been continuing since 1854 A.D., which was borrowed from the Manusmriti ( Hindu religious text) has been changed and secular constitution has been promulgated. Newly promulgated constitution is secular in nature but the Muslims are not fully satisfied.

In recent years they have tried to differentiate themselves culturally, challenging centuries old peace and harmony. In the process they have undergone a process of political Islamization and have emerged as a distinctive ethnic community. The Muslims organizations operating socioreligious activities became aggressive in challenging their centuries old subordinate status because of this constitution. This led to communal conflict in some of the Terai districts where Muslims are in competitive strength which is not a good sign for peace and harmony for the society.

\section{References}

Ali, S.A. (1981). Family life in Islam, Hakim Abdul Hameed (ed.), Delhi: Common wealth Publishers.

Banu, Q. (1980). Introduction to Muslim in Nepal. (Un-published Thesis, Department of History, Tribhuvan .University.).Kathmandu.

Bista, D.B. (1961). People of Nepal. Kathmandu: Ratna Pustak Bhandar.

Bista, D.B. (2050 B.S.). Sabai Jat Ko Phoolbari (Garden of all Castes). Kathmandu: Sajha Publication.

CBS (1993) Population census-1991.Kathmandu: Central Bureau of Statistics.

CBS (1997) Statistical year book of Nepal.Kathmandu:Central Bureau of Statistics.

CBS (2014) Statistical pocket book. Kathmandu: Central Bureau of Statistics. 
Gaborieau, M. (1981).Peasants, Urban Traders and Rural Artisans. Journal Institute of Muslim Minority Affairs. Jedda: King Abdul Aziz University

Hamidullah, M. (1969). Introduction to Islam, Paris: Centre Cultural Islamique.

Hassan, M. (1975) Some Aspects of the Problems of Muslim Social Reform (in Zafar Imam (ed.) Muslim in India), New Delhi: Orient Longman.

Hoffer A. (2004). The Caste Hierarchy and the State in Nepal: A Study of Muluki Ain of 1854.Kathmandu: Himal Books.

India Today, June 12, 2000, New Delhi.

Khan, Abdul Salam (2071B.S.) Nepal Ra Nepali Musalman (Nepal and Nepali Muslims). Kathmandu.

Kunwar, D. S. and Ojha, N. (2017). The Muslims of Nepal : Social, Historical and Economic Perspective. Kathmandu: Oxford Stores.

Manandhar, T. and Sharma N. (2053 B.S.). Adhunik Nepal Ko Rajnitik Itihas. (2007-2019 B.S.) (Political History of Modern Nepal). Kathmandu: CNAS, T.U.

Nepal Government. (2065 B.S.) Interim Constitution of Nepal-2006.. Kathmandu: Legal book Publisher.

Ojha, N.(2068 B.S.). A Study on Socio- Cultural Life of Muslims of Kathmandu, (Unpublished Research Report) submitted to research division . Tribhuvan University, Kirtipur, Kathmandu.

Ojha N. (2018). Rites and Rituals of Nepali Muslims. Kathmandu: Oxford Store.

Regmi,J.C. (2026 B.S.). Lichhavi Sanskriti. Kathmandu: Ratna Pustak Bhandar.

Seddon, D.(2018).The Muslim Communities of Nepal. New Delhi: Adroit Publishers.

Shiwakoti, G.(2072 B.S.). Nepal Ko Sambidhan (Constitution of Nepal). Kathmandu: Pairavi Prakashan.

Subedee, R.R.(2040B.S.). "Nepali Senama Muslaman haruko Prabesh”. Kathmandu.

Subedee, A.(2074 B.S. Baishak). Annapurna Post Daily.

Thapa, S. (1995). Caste Hierarchy: The inter-ethnic stratification in the Muslim society of Nepal, Tribhuvan University Journal Vol.13. The Holy Quran. Madina: The Presidency of Islamic Researches, N/D.

Whelpton, J.(2005). A History of Nepal. New Delhi : Cambridge University Press.

http:// www.nmc.gov.np

http:// Islamic bulletin.org/newsletter/issue 24/beliefs.aspx retrieved on 2020 January.

http:// islamhelpline.net/node/1354 retrieved on 2020 January. FGD with Atala Bhai, Fajir Miya, Akbar Khan, Tara Devi and Maulana Mohasin on 20 March 2015. 